\title{
Preparation of Laccase Immobilized Cryogels and Usage for Decolorization
}

\author{
Murat Uygun \\ Koçarlı Vocational and Training School, Adnan Menderes University, 09970 Aydın, Turkey \\ Correspondence should be addressed to Murat Uygun; muygun@adu.edu.tr
}

Received 29 May 2013; Revised 15 July 2013; Accepted 15 July 2013

Academic Editor: Tanaji Talele

Copyright (C) 2013 Murat Uygun. This is an open access article distributed under the Creative Commons Attribution License, which permits unrestricted use, distribution, and reproduction in any medium, provided the original work is properly cited.

Poly(methyl methacrylate-co-glycidyl methacrylate) (poly(MMA-co-GMA)) cryogels were synthesized by radical cryopolymerization technique. Then, laccase enzyme was covalently attached to the cryogel and characterized by using swelling studies and SEM and EDX analyses. Kinetic properties and optimum conditions of the immobilized and free laccase were studied and it was found that $V_{\max }$ of the immobilized laccase was lower than that of free laccase. $K_{m}$ of the immobilized laccase was increased upon immobilization. Optimum $\mathrm{pH}$ was found to be 4.0 for each type of laccase, while optimum temperature was shifted to the warmer region after the immobilization. It was also found that thermal stability of the immobilized laccase was higher than that of free laccase. Immobilized laccase could be used for 10 times successive reuse with no significant decrease in its activity. Also, these laccase immobilized cryogels were successfully used for the decolorization of seven different dyes.

\section{Introduction}

Laccase (benzenediol:oxygen oxidoreductase, EC 1.10.3.2) is a copper bearing enzyme in multicopper family which is produced by various plants and secreted by diverse fungi species which have lignin degradation capability [1]. Recently some bacterial species which demonstrate laccase activity were also characterized. Laccase oxidize a wide variety of the phenolic compounds and aromatic amines by catalyzing the reaction of the one electron oxidation of phenols, anilines, and aromatic thiols to their radicals with parallel reduction of oxygen to water [2]. Substrate specificity of the laccase is broad and it can oxidize not only these compounds but also nonphenolic substances [3]. Laccase can be used in various industrial applications such as pulp delignification, wood fiber modification, dye or stain bleaching, chemical or medicinal synthesis, and contaminated water or soil remediation due to its wide specificity behavior against its nonspecific substrates [4]. Besides all these, one of the unique properties of laccase is the capability for degradation of dyes. The enzyme can decolorize various dyes such as azo, anthraquinone, and triphenylmethane, through nonspecific free radical mechanism with creation of phenolic compounds $[5,6]$.

Using the laccase in industrial applications has some limitations such as low stability and productivity and its high production cost [7]. In order to improve the reusability of the enzymes, increase the enzyme stability, and reduce the cost, laccase has been immobilized successfully on various support materials such as magnetic chitosan microspheres [1], nonporous poly(GMA/EGDMA) beads [8], polyamide 6,6 fibers [9], poly(glycidyl methacrylate) brush grafted poly(hydroxyethyl methacrylate) films [10], methylene blue modified mesoporous silica MCM-41/PVA [11], magnetic mesoporous silica nanoparticle [7], alginate/gelatin blent with PEG [12], epoxy-activated Sepabeads EC-EP3 and Dilbeads NK [4], alginate-chitosan microcapsules [13], and PVA cryogel [14].

There is a great interest in the area of the improvement and development of new materials which are used for the bioseparation processes due to the ever growing demands for the biologically active pure compounds (low molecular weight compounds, biopolymers such as DNA and proteins, 
viruses, cell organelles, and cells) [15]. For this reason, development of macroporous polymeric materials has attracted great attention especially in biomedical, biotechnological, and medical purposes [16]. One of the new types of polymeric materials which have significant potential in biotechnology is cryogels. They are synthesized at frozen temperature and thus are named as cryogel (in Greek, frozen or ice). Cryogels are extremely porous polymeric materials and can be synthesized in various morphology and porosity by using any of the gel producing precursors [15]. Nowadays, cryogels find too many usages in various biotechnological applications as a chromatographic material, a support material for immobilization of molecules and cells, a matrix for electrophoresis and immunodiffusion, and a gel support for solid culture media [17]. Basic application areas of the cryogels are biocatalysis with immobilized enzymes and cells; bioseparation for purification of target molecules; chromatography of cell organelles, viruses, microbial, and mammalian cells; and three-dimensional matrix for mammalian cell culture [16].

Dyes are widely used in textile, paper, cosmetic, pharmaceutical, and dyeing and printing industries, and the effluents from these industries were released to the environment. This effluent contains environmentally hazardous polluting agents such as pesticides, heavy metals, pigments, and dyes. The degradation of these dye bearing effluents is not too easy and conventional treatment techniques (such as activated sludge, trickling filters, adsorption, coagulation-flocculation, ion-exchange, oxidation, electrochemical methods, etc.) does not effectively degrade them due to the complex structure of the effluent, besides these techniques may also generate hazardous byproducts $[3,18]$. These treatment techniques are highly expensive and because of this their application in industrial waste treatment is also limited. In recent years, there is a great attention to the use of microbial enzymes for dye decolorization applications due to their effective treatment behavior [19]. For these purposes, laccase has been widely used for decolorization of variety of synthetic dyes such as Remazol Brilliant Blue [4, 20-22], Acid Green 27, Acid Violet 7 and Indigo Carmine [23], Neolane Yellow, Maxilon Blue, Neolane Pink, Basacryl Yellow, Neolane Blue and Bezaktiv Yellow [3], Remazol Black-5 [19, 21], Acid Blue 62, Acid Blue 40, Reactive Blue 81, Direct Black 22, Acid Red 27 [24], Reactive Red 251, Reactive Orange 122 [21], Reactive Black 5, Acid Blue 25, Methyl Orange, Methyl Green, Acid Green 27 [4], Direct Red 28, Acid Orange 74, Reactive Blue 15, Acid Blue 74, Reactive Blue 19, Azure B [25], Bromophenol Blue, Naphthol Blue, and Methyl Red [26].

In this paper, decolorization efficiency of the immobilized laccase was studied. For these purposes, poly(methyl methacrylate-co-glycidyl methacrylate) (poly(MMA-co-GMA)) cryogels were synthesized with cryopolymerization technique. Prepared cryogels were characterized by using SEM and EDX analyses and swelling studies. Then, laccase was covalently immobilized onto these newly synthesized cryogels. Kinetic parameters of free and immobilized laccase were also investigated and optimum $\mathrm{pH}$ and temperature profiles were studied. Also, thermal stability of the free and immobilized form of laccase was investigated. Finally, decolorization capability of the immobilized laccase was studied with various dyes.

\section{Experimental}

2.1. Materials. Laccase (from Trametes versicolor), methyl methacrylate, glycidyl methacrylate, $\mathrm{N}, \mathrm{N}^{\prime}$-methylene-bisacrylamide (MBAAm), ammonium persulfate (APS), and $\mathrm{N}$, $\mathrm{N}, \mathrm{N}^{\prime}, \mathrm{N}^{\prime}$,-tetramethylene diamine (TEMED) were supplied from Sigma (St. Louis, USA). All other chemicals were of reagent grade and purchased from Aldrich (Steinheim, Germany).

2.2. Synthesis of Poly(MMA-co-GMA) Cryogel. Poly(MMAco-GMA) cryogel was synthesized with free radical cryopolymerization technique [27]. Polymerization procedure was explained as follows. Firstly, $0.283 \mathrm{~g}$ of MBBAm was dissolved in $10.0 \mathrm{~mL}$ of distilled water and mixed with $5.0 \mathrm{~mL}$ of MMA and GMA solution which was prepared by dissolving $1.07 \mathrm{~mL}$ of MMA and $100 \mu \mathrm{L}$ of GMA in $10.0 \mathrm{~mL}$ of distilled water. Then, $20.0 \mathrm{mg}$ of APS and $25 \mu \mathrm{L}$ of TEMED were added to this mixture and polymerization reaction was initiated. Resulting solution was immediately poured to the syringe and was frozen at $-12^{\circ} \mathrm{C}$ for $24 \mathrm{~h}$. After this polymerization period, prepared cryogel was washed with distilled water in order to remove unreacted monomers and initiators. Chemical structure of the poly(MMA-co-GMA) cryogel was shown in Figure 1.

\subsection{Immobilization of Laccase onto Poly(MMA-co-GMA)} Cryogel. Laccase immobilization experiments were carried out according to the literature described [28]. Briefly, poly(MMA-co-GMA) cryogel was equilibrated with $\mathrm{pH} 8.0$ phosphate buffer $(50 \mathrm{mM})$ for $2 \mathrm{~h}$. Then, $20.0 \mathrm{~mL}$ of laccase solution $(2.0 \mathrm{mg} / \mathrm{mL}$ in $\mathrm{pH} 8.0$ phosphate buffer) was passed through the cryogel column ( 0.335 g-dry weight) by using a peristaltic pump at $22^{\circ} \mathrm{C}$ for $18 \mathrm{~h}$. Covalent attachment between the cryogel and laccase molecule was carried out by the help of epoxy groups of the GMA monomer in the cryogel structure. Immobilization of the laccase onto poly(MMA-coGMA) cryogel was schematically demonstrated in Figure 2. Immobilized amount of laccase was determined by measuring the initial and final laccase concentrations with the method of Bradford [29].

2.4. Characterization of Poly(MMA-co-GMA) Cryogel. Energy Dispersive X-Ray (EDX) analysis of cryogel was carried out by using an EDX instrument (LEO, EVO 40, Carl Zeiss NTS, USA). Pore size and cryogel morphology were investigated with Scanning Electron Microscopy (SEM). For this, cryogel was dried and coated with one layer of gold and then, SEM photograph of cryogel was taken by using an SEM device (Philips XL-30S FEG, The Netherland). Swelling degree $(S)$ of poly(MMA-co-GMA) and laccase immobilized poly(MMA-co-GMA) cryogels were also determined. For this, cryogels were dried at $60^{\circ} \mathrm{C}$ for 3 days and weighed $\left(m_{d}\right)$. Then, cryogels were placed in $50.0 \mathrm{~mL}$ of distilled water at 


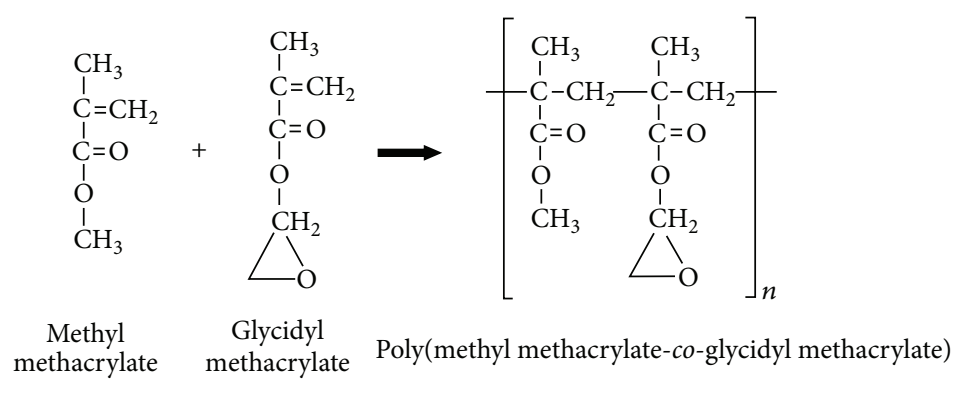

FIGURE 1: Chemical structure of poly(MMA-co-GMA) cryogel.

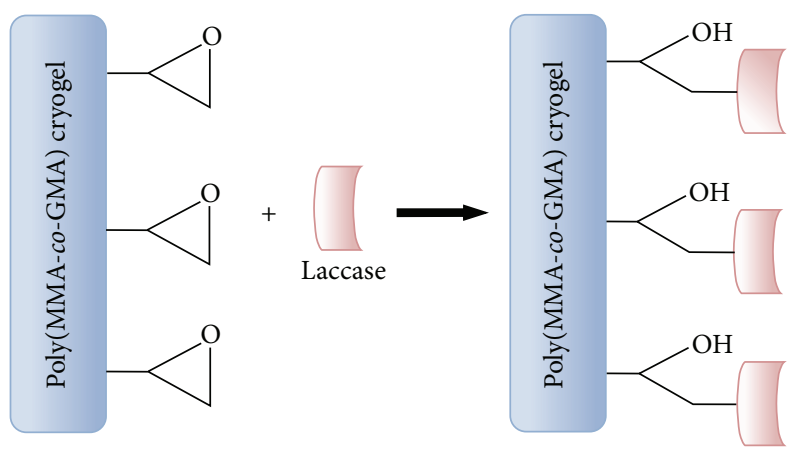

FIGURE 2: Schematic presentation of the immobilization of laccase onto cryogel structure.

$25^{\circ} \mathrm{C}$ for $2 \mathrm{~h}$. Swelled cryogels were taken out from water and weighed $\left(m_{s}\right)$ and the swelling degree was calculated as [27]

$$
S=\frac{m_{s}-m_{d}}{m_{d}}
$$

2.5. Laccase Activity Studies. Laccase activity was determined by using the 2,2' -azinobis-(3-ethylbenzthiazoline-6sulfonate) (ABTS) as a substrate [30]. For free enzyme, $0.1 \mathrm{~mL}$ of ABTS solution $(10.0 \mathrm{mM})$ was mixed with $880 \mu \mathrm{L}$ of $\mathrm{pH} 4.0$ acetate buffer solution $(100 \mathrm{mM})$ and incubated at $25^{\circ} \mathrm{C}$ for $20 \mathrm{~min}$. Then, enzymatic reaction was initiated with addition of $20 \mu \mathrm{L}$ of enzyme solution. Activity of the immobilized laccase was determined in continuous system. For this, $10 \mathrm{~mL}$ of ABTS $(10.0 \mathrm{mM})$ in acetate buffer $(\mathrm{pH} 4.0,100 \mathrm{mM})$ was used as a substrate solution and passed through the laccase immobilized cryogel. The activity of the free and immobilized form of laccase was measured by using the increase in absorbance at $420 \mathrm{~nm}$. One unit of laccase activity is defined as the required enzyme amount for the oxidation of $1.0 \mu \mathrm{mol}$ of ABTS per min at $25^{\circ} \mathrm{C}$.

2.6. Determination of Kinetic and Optimal Properties of Free and Immobilized Laccase. In order to determine the $K_{m}$ and $V_{\max }$ values of the free and immobilized form of laccase, initial ABTS concentrations were changed between 1.0 and $10.0 \mathrm{mM}$ in $\mathrm{pH} 4.0$ acetate buffer $(100 \mathrm{mM})$ at $25^{\circ} \mathrm{C}$. Activity studies of the free and immobilized form of laccase were performed in the $\mathrm{pH}$ range of 3.0-6.0 by using $0.1 \mathrm{M}$ of acetate buffer (for $\mathrm{pH} 3.0-4.5$ ) and $0.1 \mathrm{M}$ of phosphate buffer

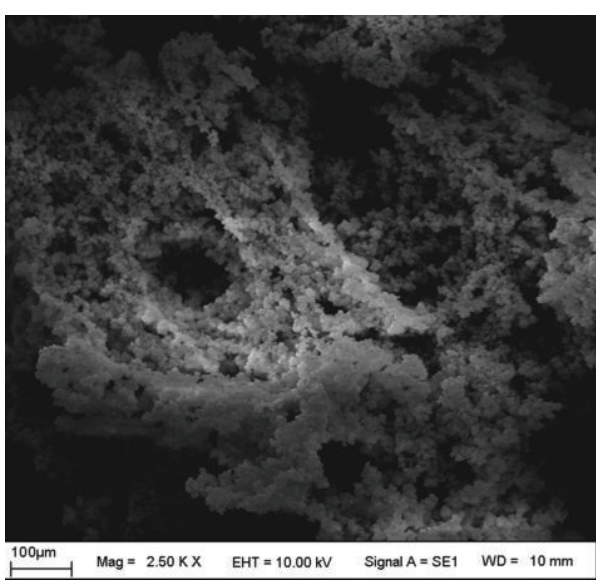

FIGURE 3: SEM photograph of the poly(MMA-co-GMA) cryogel.

(for $\mathrm{pH}$ 5.0-6.0), in order to determine the optimum $\mathrm{pH}$ profiles of two laccase forms. In order to determine the optimum temperature of the laccase, medium temperature was changed between 4.0 and $60^{\circ} \mathrm{C}$. Thermal stability of free and immobilized laccase was also determined at 55 and $65^{\circ} \mathrm{C}$. For this, enzyme preparations were incubated at 55 and $65^{\circ} \mathrm{C}$ and activities of the enzymes were measured with the above mentioned method with defined time intervals for $5 \mathrm{~h}$. In order to investigate the operational stability of the immobilized laccase, activity measurements were repeated for 10 times. Storage stability of free and immobilized laccase was also investigated for 30 days. For this purpose, enzyme preparations were stored at $+4^{\circ} \mathrm{C}$ and activities of the enzymes were determined at the beginning and at the end of 30 days of storage. After each activity experiments, immobilized cryogels were washed with water and equilibrated with $\mathrm{pH}$ 4.0 acetate buffer $(100 \mathrm{mM})$ for next activity study.

2.7. Decolorization Studies. Seven different dyes Procion Red $\left(\lambda_{\max }: 536 \mathrm{~nm}\right)$, Reactive Green $5\left(\lambda_{\max }: 674 \mathrm{~nm}\right)$, Reactive Brown $10\left(\lambda_{\max }: 526 \mathrm{~nm}\right)$, Reactive Green $19\left(\lambda_{\max }: 631 \mathrm{~nm}\right)$, Cibacron Blue F3GA $\left(\lambda_{\max }: 605 \mathrm{~nm}\right)$, Alkali Blue 6B $\left(\lambda_{\max }\right.$ : $587 \mathrm{~nm})$, and Brilliant Blue $6\left(\lambda_{\max }: 607 \mathrm{~nm}\right)$ ) were used for the investigation of the decolorization efficiency of the laccase immobilized poly(MMA-co-GMA) cryogel. For this, $10.0 \mathrm{~mL}$ of dye solution $(0.1 \mathrm{mg} / \mathrm{mL})$ was passed through the laccase immobilized cryogel column by using a peristaltic pump at 


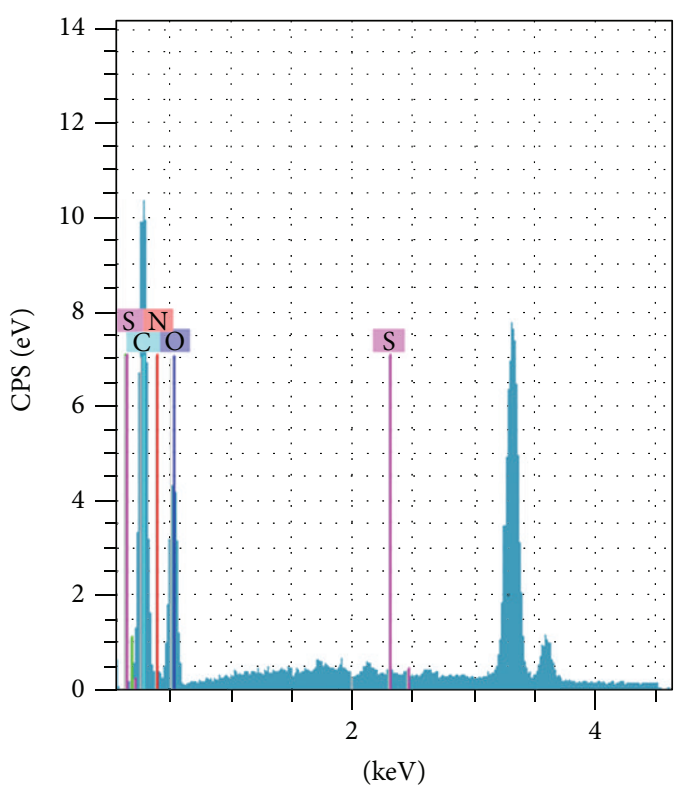

FIGURE 4: EDX spectrum of the laccase immobilized poly(MMA-coGMA) cryogel.

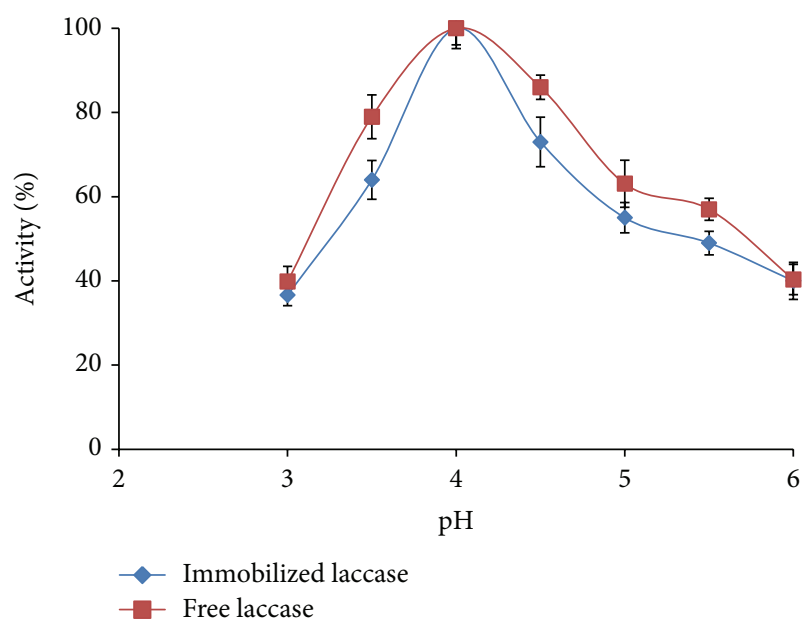

FIGURE 5: Effect of $\mathrm{pH}$ on the activity of free and immobilized form of laccase.

the flow rate of $0.5 \mathrm{~mL} / \mathrm{min}$. Decolorization activity was monitored photometrically by using a UV-Vis spectrophotometer (Shimadzu, 1601, Japan) for $10 \mathrm{~min}$.

All measurements were repeated three times and the average values were used for all calculations.

\section{Results and Discussion}

3.1. Synthesis and Characterization of Poly(MMA-co-GMA) Cryogel. Synthesized poly(MMA-co-GMA) cryogel had sponge-like morphology and was elastic and opaque. When compressed by hand, cryogel lost all water accumulated inside the pores. This cryogel exhibited fast swelling properties, and when dried cryogel was submerged in water,

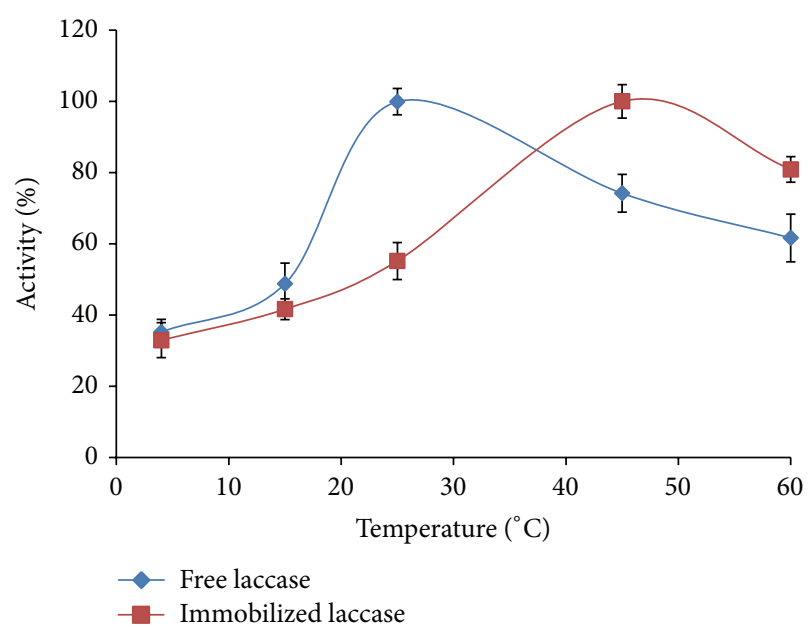

FIGURE 6: Effect of temperature on the activity of free and immobilized form of laccase.

TABLE 1: Kinetic constants of the free and immobilized laccase.

\begin{tabular}{lcc}
\hline Enzyme type & $K_{m}(\mathrm{mM})$ & $V_{\max }(\mu \mathrm{mol} / \mathrm{min})$ \\
\hline Free & 5.26 & 0.016 \\
Immobilized & 11.11 & 0.013 \\
\hline
\end{tabular}

it swelled rapidly and restored its original shape and size within 1-2 min. Internal structure and morphology of the poly(MMA-co-GMA) cryogel was shown in Figure 3. As shown in the figure, cryogel had a macroporous structure and pore diameter was found in the range of $10-100 \mu \mathrm{m}$. EDX analysis of the laccase immobilized poly(MMA-coGMA) cryogel was demonstrated in Figure 4. As seen here, synthesized laccase immobilized cryogel composed of $\mathrm{C}, \mathrm{O}, \mathrm{N}$ and $\mathrm{S}$ atoms. As clearly seen here that, while the poly(MMAco-GMA) cryogel contained only $\mathrm{C}$ and $\mathrm{O}$ atoms, additional $\mathrm{N}$ and $\mathrm{S}$ atoms appeared here due to the incorporation of protein structured laccase onto the cryogenic structure. Immobilized amount of laccase was also investigated and it was found to be $51.7 \mathrm{mg} / \mathrm{g}$ cryogel. Specific activities of free and immobilized form of laccase were determined as $8.9 \times 10^{-3} \mathrm{U} / \mathrm{mg}$ and $7.7 \times 10^{-3} \mathrm{U} / \mathrm{mg}$, respectively. As stated here, activity of laccase decreased slightly upon immobilization, and this decrease is carried out probably due to the certain conformational changes which were taken place upon immobilization. The equilibrium swelling degree of the poly(MMA-co-GMA) and laccase immobilized poly(MMA-co-GMA) cryogels were calculated as $8.21 \mathrm{~g}$ $\mathrm{H}_{2} \mathrm{O} / \mathrm{g}$ cryogel and $9.93 \mathrm{~g} \mathrm{H}_{2} \mathrm{O} / \mathrm{g}$ cryogel, respectively. It can be concluded from this result that swelling degree of the cryogel increased with incorporation of laccase onto the cryogel structure.

3.2. Kinetic and Optimal Properties of Free and Immobilized Laccase. The kinetic constants of free and immobilized form of laccase were summarized in Table 1 . As seen in the table, $V_{\max }$ value of laccase decreased upon immobilization from 0.016 to $0.013 \mu \mathrm{mol} / \mathrm{min}$. The $K_{m}$ value of immobilized 


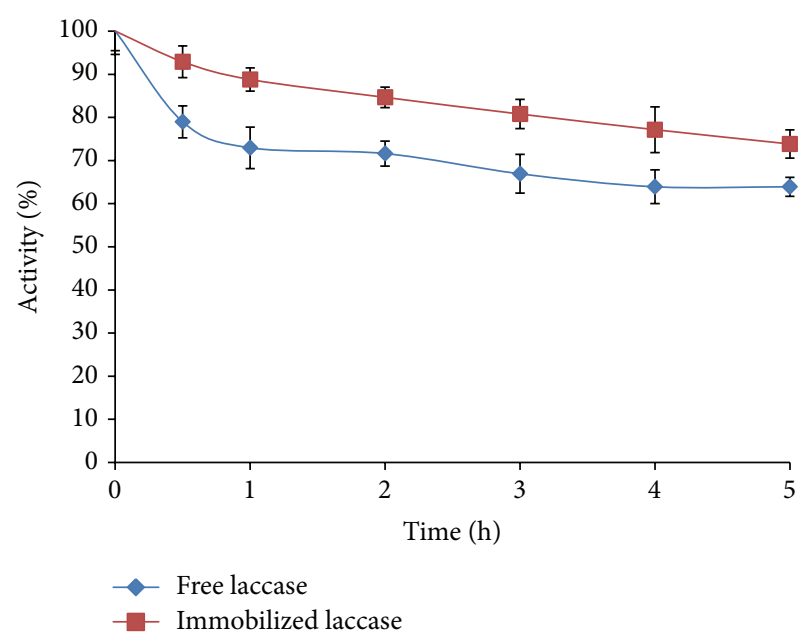

(a)

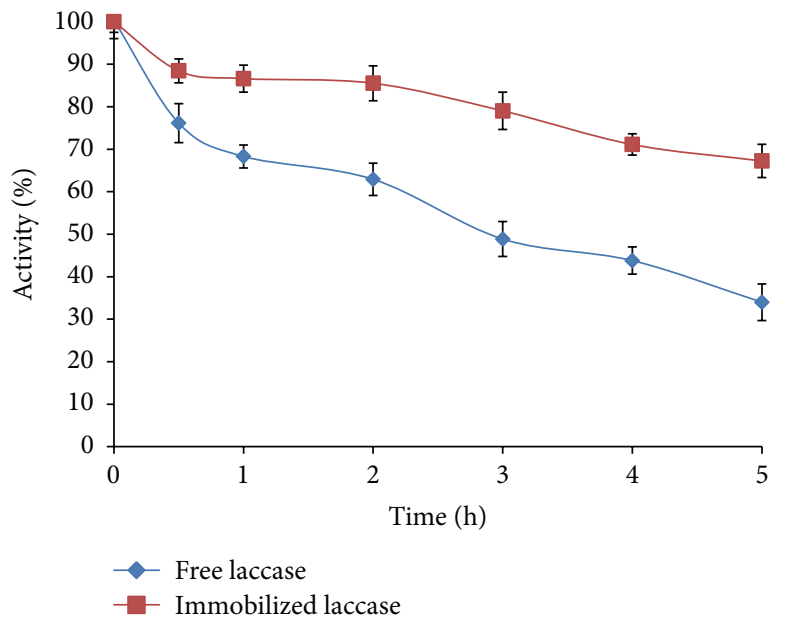

(b)

Figure 7: Thermal stability profile of the free and immobilized laccase at $55^{\circ} \mathrm{C}$ (a) and $65^{\circ} \mathrm{C}(\mathrm{b})$.

laccase $(11.11 \mathrm{mM})$ was about 2 times higher than that of free laccase $(5.26 \mathrm{mM})$. This increase in $K_{m}$ value indicated that affinity of the laccase to its substrate decreased with immobilization. These decreases in the activity were probably due to the steric hindrances caused by the support or decrease in the enzyme flexibility or diffusional limitations of substrate [1]. Effect of $\mathrm{pH}$ on the activity of the free and immobilized laccase was demonstrated in Figure 5. As seen in figure, maximum activity was observed at $\mathrm{pH} 4.0$ for both free and immobilized laccase. Above and below this $\mathrm{pH}$ value, enzymatic activity of the laccase decreased dramatically. Optimum temperature profile of free and immobilized laccase was shown in Figure 6. As seen here, optimum temperatures of free and immobilized laccase were found to be 25 and $45^{\circ} \mathrm{C}$, respectively. This shift towards the higher temperature brings about very important property to the immobilized form of laccase. Dyeing and painting process generally carried out at high temperatures and effluents from these industries are also protecting their temperatures. Cooling is often time consuming and it is essential to treat them even if they are already hot. Immobilized laccase with optimum temperature at $45^{\circ} \mathrm{C}$ may be successfully applicable for the decolorization of such wastes. The same thermal property of the immobilized laccase was also monitored with the thermal stability studies. Thermal stability profiles of the free and immobilized laccase were investigated at 55 and $65^{\circ} \mathrm{C}$ and findings were demonstrated in Figures 7(a) and $7(\mathrm{~b})$, respectively. As seen in the figure, while free laccase protected $64 \%$ of its initial activity at the end of $5 \mathrm{~h}$ incubation at $55^{\circ} \mathrm{C}$, immobilized laccase showed $77 \%$ of initial activity. The same finding also monitored at $65^{\circ} \mathrm{C}$, immobilized laccase demonstrated $67 \%$ of its initial activity at the end of $5 \mathrm{~h}$ incubation, while free laccase showed only $34 \%$. From these results, it can be concluded that thermal stability and resistance of the laccase were increased with immobilization process. These findings can also enhance the usability of the immobilized form laccase in waste water

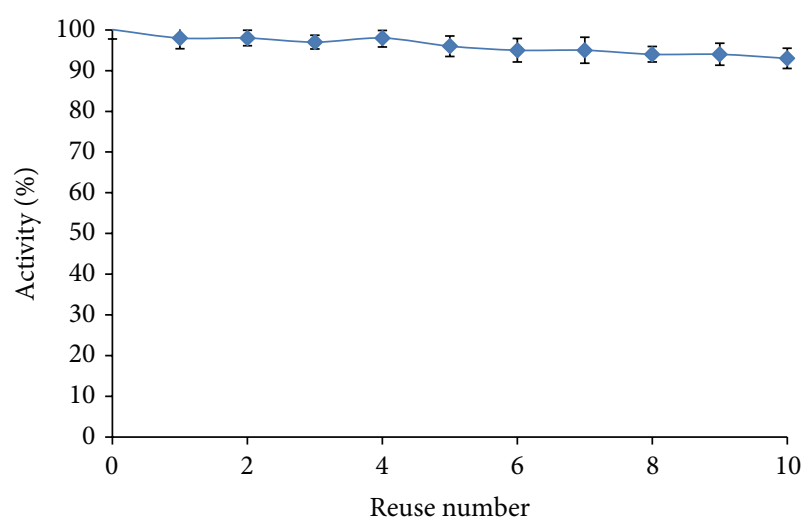

FIGURE 8: Operational stability of the immobilized laccase.

management. Operational stability profile of the immobilized laccase was demonstrated in Figure 8. As demonstrated in figure, operational stability of the immobilized laccase was found to be very high. At the end of the 10th reuse, activity of the immobilized laccase decreased only about $6.7 \%$. Storage stability of the free and immobilized form of laccase was also determined and it was found that while immobilized enzyme protected $85.5 \%$ of its initial activity, free preparation protected $52.8 \%$ of its initial activity, at the end of the 30 days.

3.3. Decolorization Studies. Decolorization efficiency of immobilized laccase was demonstrated in Figure 9. As seen here, immobilized laccase decolorized the studied seven dyes effectively. All dyes decolorized by using immobilized laccase at the rate of $50 \%$ at the end of $10 \mathrm{~min}$. Decolorization percentage of the dyes were also given in Table 2. Murugesan et al. [19] used laccase from Ganoderma lucidum for decolorization of Remazol Brilliant Blue $\mathrm{R}$ and they found that Remazol Brilliant Blue $\mathrm{R}$ was decolorized by $77.4 \%$ within $2 \mathrm{~h}$. Peralta-Zamora et al. [21] investigated that the 
TABLE 2: Decolorization percentage of dyes at the end of $10 \mathrm{~min}$.

\begin{tabular}{lccccccc}
\hline Dyes & $\begin{array}{c}\text { Procion } \\
\text { Red }\end{array}$ & $\begin{array}{c}\text { Reactive } \\
\text { Green 5 }\end{array}$ & $\begin{array}{c}\text { Reactive } \\
\text { Brown 10 }\end{array}$ & $\begin{array}{c}\text { Reactive } \\
\text { Green 19 }\end{array}$ & $\begin{array}{c}\text { Cibacron Blue } \\
\text { F3GA }\end{array}$ & $\begin{array}{c}\text { Alkali } \\
\text { Blue 6B }\end{array}$ & $\begin{array}{c}\text { Brilliant } \\
\text { Blue 6 }\end{array}$ \\
\hline Decolorization \% & 81.53 & 59.81 & 73.59 & 66.33 & 62.95 & 59.71 & 61.68 \\
\hline
\end{tabular}

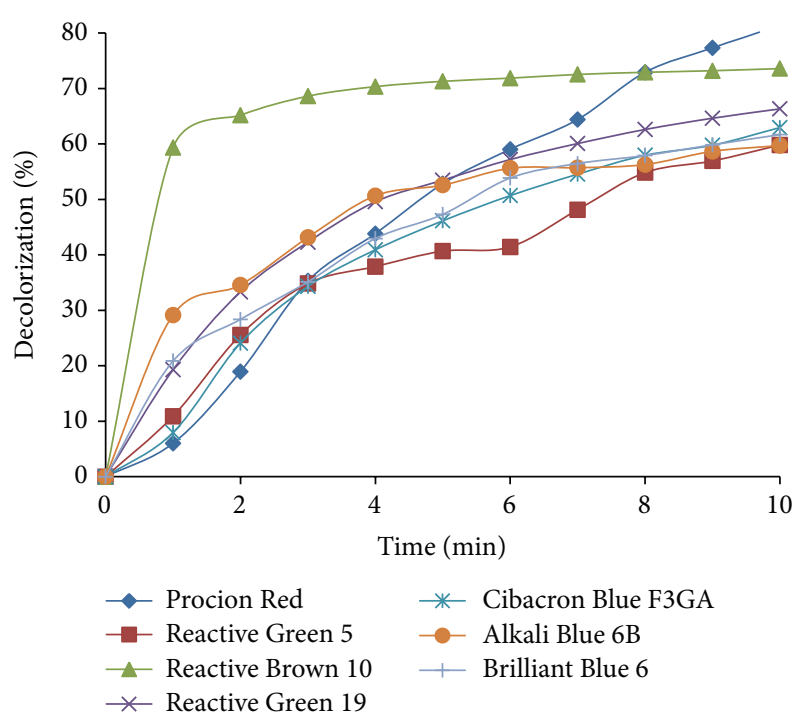

FIGURE 9: Decolorization efficiency of immobilized laccase onto poly(MMA-co-GMA) cryogel.

decolorization of Remazol Brilliant Blue R, Remazol Black B, Reactive Orange 122, and Reactive Red 251 dyes by using immobilized laccase within $30 \mathrm{~min}$ and decolorization capacities were found to be $35-45 \%, 10 \%, 10-30 \%$, and 5-55\%, respectively. Kunamneni et al. [4] used immobilized form of laccase in order to decolorize the synthetic dyes and they found $61-82 \%$ decolorization rates within $6 \mathrm{~h}$. Claus et al. [25] used laccase from Trametes versicolor for decolorization of azo dyes and they reached 3.0\%-82\% decolorization efficiency within $16 \mathrm{~h}$. Murugesan et al. [6] purified laccase enzyme from Pleurotus sajor-caju and used for the decolorization of three azo dyes. Investigators found $70-90 \%$ decolorization yield within $24 \mathrm{~h}$. One of the most important features of laccase immobilized poly(MMA-coGMA) cryogel was its speed. It reached high decolorization values only within $10 \mathrm{~min}$ and it can be concluded form these results that immobilized from of laccase was successfully used for the decolorization of dyes by using a continuous system and this system can be adapted to the industrial waste water management system as a decolorization agent.

\section{Conclusion}

Dye effluents cause serious environmental pollution and management of these effluents is difficult due to the complex structure of the dye wastes and used techniques for these purposes are very expensive. For these purposes, new decolorization techniques have been developed and used for management of the dye effluents. Laccase has been used extremely for the decolorization process due to its unique enzymatic properties. Its immobilized form especially, has been used in various decolorization studies. One of the new polymeric materials which are used intensively in biotechnological area is cryogel. Preparation of these polymeric materials is easy and can be produced in desired shape, size, and functionalities. In this presented work, laccase was successfully immobilized onto poly(MMA-co-GMA) cryogel and decolorization properties of this preparation was investigated. It was shown that, this new immobilized laccase preparation was used for decolorization of seven different dyes and decolorized all studied dyes effectively. It can be concluded from these results that this new laccase immobilized cryogenic medium can be used for the decolorization of the dye and paint industry effluents and the other dye bearing waste waters.

\section{Conflict of Interests}

No conflict of interests was declared.

\section{References}

[1] D.-S. Jiang, S.-Y. Long, J. Huang, H.-Y. Xiao, and J. Y. Zhou, "Immobilization of Pycnoporus sanguineus laccase on magnetic chitosan microspheres," Biochemical Engineering Journal, vol. 25, no. 1, pp. 15-23, 2005.

[2] S. Camarero, D. Ibarra, M. J. Martínez, and Á. T. Martínez, "Lignin-derived compounds as efficient laccase mediators for decolorization of different types of recalcitrant dyes," Applied and Environmental Microbiology, vol. 71, no. 4, pp. 1775-1784, 2005.

[3] H. Zouari-Mechichi, T. Mechichi, A. Dhouib, S. Sayadi, A. T. Martínez, and M. J. Martínez, "Laccase purification and characterization from Trametes trogii isolated in Tunisia: decolorization of textile dyes by the purified enzyme," Enzyme and Microbial Technology, vol. 39, no. 1, pp. 141-148, 2006.

[4] A. Kunamneni, I. Ghazi, S. Camarero, A. Ballesteros, F. J. Plou, and M. Alcalde, "Decolorization of synthetic dyes by laccase immobilized on epoxy-activated carriers," Process Biochemistry, vol. 43, no. 2, pp. 169-178, 2008.

[5] A. Zille, B. Gornacka, A. Rehorek, and A. Cavaco-Paulo, "Degradation of azo dyes by Trametes villosa laccase over long periods of oxidative conditions," Applied and Environmental Microbiology, vol. 71, no. 11, pp. 6711-6718, 2005.

[6] K. Murugesan, M. Arulmani, I.-H. Nam, Y.-M. Kim, Y.-S. Chang, and P. T. Kalaichelvan, "Purification and characterization of laccase produced by a white rot fungus Pleurotus sajorcaju under submerged culture condition and its potential in decolorization of azo dyes," Applied Microbiology and Biotechnology, vol. 72, no. 5, pp. 939-946, 2006.

[7] F. Wang, C. Guo, L.-R. Yang, and C.-Z. Liu, "Magnetic mesoporous silica nanoparticles: fabrication and their laccase immobilization performance," Bioresource Technology, vol. 101, no. 23, pp. 8931-8935, 2010. 
[8] M. Y. Arica, B. Altintaş, and G. Bayramoǧlu, "Immobilization of laccase onto spacer-arm attached non-porous poly(GMA/ EGDMA) beads: application for textile dye degradation," Bioresource Technology, vol. 100, no. 2, pp. 665-669, 2009.

[9] C. Silva, C. J. Silva, A. Zille, G. M. Guebitz, and A. CavacoPaulo, "Laccase immobilization on enzymatically functionalized polyamide 6,6 fibres," Enzyme and Microbial Technology, vol. 41, no. 6-7, pp. 867-875, 2007.

[10] G. Bayramoğlu and M. Y. Arica, "Immobilization of laccase onto poly(glycidylmethacrylate) brush grafted poly(hydroxyethylmethacrylate) films: enzymatic oxidation of phenolic compounds," Materials Science and Engineering C, vol. 29, no. 6, pp. 1990-1997, 2009.

[11] X. Xu, P. Lu, Y. Zhou, Z. Zhao, and M. Guo, "Laccase immobilized on methylene blue modified mesoporous silica MCM41/PVA," Materials Science and Engineering C, vol. 29, no. 7, pp. 2160-2164, 2009.

[12] P. Wang, X. Fan, L. Cui, Q. Wang, and A. Zhou, "Decolorization of reactive dyes by laccase immobilized in alginate/gelatin blent with PEG," Journal of Environmental Sciences, vol. 20, no. 12, pp. 1519-1522, 2008.

[13] L. Lu, M. Zhao, and Y. Wang, "Immobilization of laccase by alginate-chitosan microcapsules and its use in dye decolorization," World Journal of Microbiology and Biotechnology, vol. 23, no. 2, pp. 159-166, 2007.

[14] M. D. Stanescu, M. Fogorasi, B. L. Shaskolskiy, S. Gavrilas, and V. I. Lozinsky, "New potential biocatalysts by laccase immobilization in PVA cryogel type carrier," Applied Biochemistry and Biotechnology, vol. 160, no. 7, pp. 1947-1954, 2010.

[15] M. B. Dainiak, I. Y. Galaev, A. Kumar, F. M. Plieva, and B. Mattiasson, "Chromatography of living cells using supermacroporous hydrogels, cryogels," Advanced Biochemical Engineering and Biotechnology, vol. 106, pp. 101-127, 2007.

[16] F. M. Plleva, I. Y. Galaev, and B. Mattiasson, "Macroporous gels prepared at subzero temperatures as novel materials for chromatography of particulate-containing fluids and cell culture applications," Journal of Separation Science, vol. 30, no. 11, pp. 1657-1671, 2007.

[17] V. I. Lozinsky, I. Y. Galaev, F. M. Plieva, I. N. Savina, H. Jungvid, and B. Mattiasson, "Polymeric cryogels as promising materials of biotechnological interest," Trends in Biotechnology, vol. 21, no. 10, pp. 445-451, 2003.

[18] S. R. Couto, M. Sanroman, and G. M. Gübitz, "Influence of redox mediators and metal ions on synthetic acid dye decolourization by crude laccase from Trametes hirsuta," Chemosphere, vol. 58, no. 4, pp. 417-422, 2005.

[19] K. Murugesan, I.-H. Nam, Y.-M. Kim, and Y.-S. Chang, "Decolorization of reactive dyes by a thermostable laccase produced by Ganoderma lucidum in solid state culture," Enzyme and Microbial Technology, vol. 40, no. 7, pp. 1662-1672, 2007.

[20] H. Hou, J. Zhou, J. Wang, C. Du, and B. Yan, "Enhancement of laccase production by Pleurotus ostreatus and its use for the decolorization of anthraquinone dye," Process Biochemistry, vol. 39, no. 11, pp. 1415-1419, 2004.

[21] P. Peralta-Zamora, C. M. Pereira, E. R. L. Tiburtius et al., "Decolorization of reactive dyes by immobilized laccase," Applied Catalysis B, vol. 42, no. 2, pp. 131-144, 2003.

[22] G. M. B. Soares, M. Costa-Ferreira, and M. T. Pessoa de Amorim, "Decolorization of an anthraquinone-type dye using a laccase formulation," Bioresource Technology, vol. 79, no. 2, pp. 171-177, 2001.
[23] Y. Wong and J. Yu, "Laccase-catalyzed decolorization of synthetic dyes," Water Research, vol. 33, no. 16, pp. 3512-3520, 1999.

[24] A. Michniewicz, S. Ledakowicz, R. Ullrich, and M. Hofrichter, "Kinetics of the enzymatic decolorization of textile dyes by laccase from Cerrena unicolor," Dyes and Pigments, vol. 77, no. 2, pp. 295-302, 2008.

[25] H. Claus, G. Faber, and H. König, "Redox-mediated decolorization of synthetic dyes by fungal laccases," Applied Microbiology and Biotechnology, vol. 59, no. 6, pp. 672-678, 2002.

[26] M. Nagai, T. Sato, H. Watanabe, K. Saito, M. Kawata, and H. Enei, "Purification and characterization of an extracellular laccase from the edible mushroom Lentinula edodes, and decolorization of chemically different dyes," Applied Microbiology and Biotechnology, vol. 60, no. 3, pp. 327-335, 2003.

[27] M. Uygun, D. A. Uygun, E. Özçalişkan, S. Akgöl, and A. Denizli, "Concanavalin A immobilized poly(ethylene glycol dimethacrylate) based affinity cryogel matrix and usability of invertase immobilization," Journal of Chromatography B, vol. 887-888, pp. 73-78, 2012.

[28] G. Bayramoǧlu, S. Akgöl, A. Bulut, A. Denizli, and M. Y. Arica, "Covalent immobilisation of invertase onto a reactive film composed of 2-hydroxyethyl methacrylate and glycidyl methacrylate: properties and application in a continuous flow system," Biochemical Engineering Journal, vol. 14, no. 2, pp. 117126, 2003.

[29] M. M. Bradford, "A rapid and sensitive method for the quantitation of microgram quantities of protein utilizing the principle of protein dye binding," Analytical Biochemistry, vol. 72, no. 1-2, pp. 248-254, 1976.

[30] M. D. Stanescu, S. Gavrilas, R. Ludwig, D. Haltrich, and V. I. Lozinsky, "Preparation of immobilized Trametes pubescens laccase on a cryogel-type polymeric carrier and application of the biocatalyst to apple juice phenolic compounds oxidation," European Food Research and Technology, vol. 234, no. 4, pp. 655$662,2012$. 

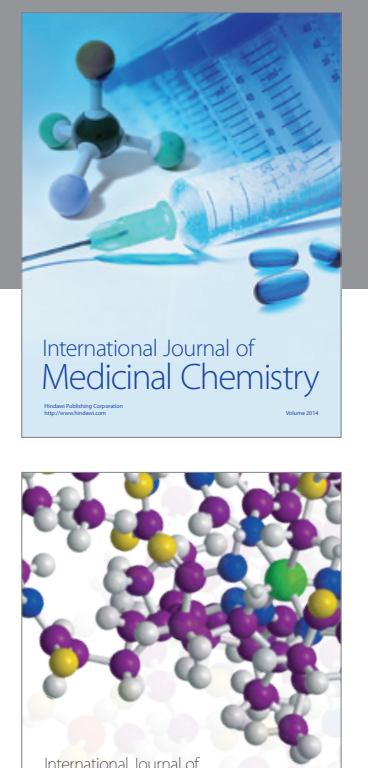

\section{Carbohydrate} Chemistry

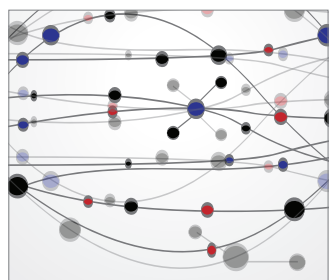

The Scientific World Journal
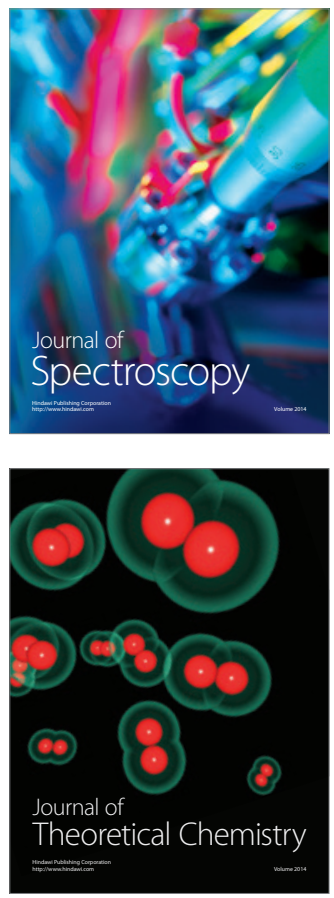
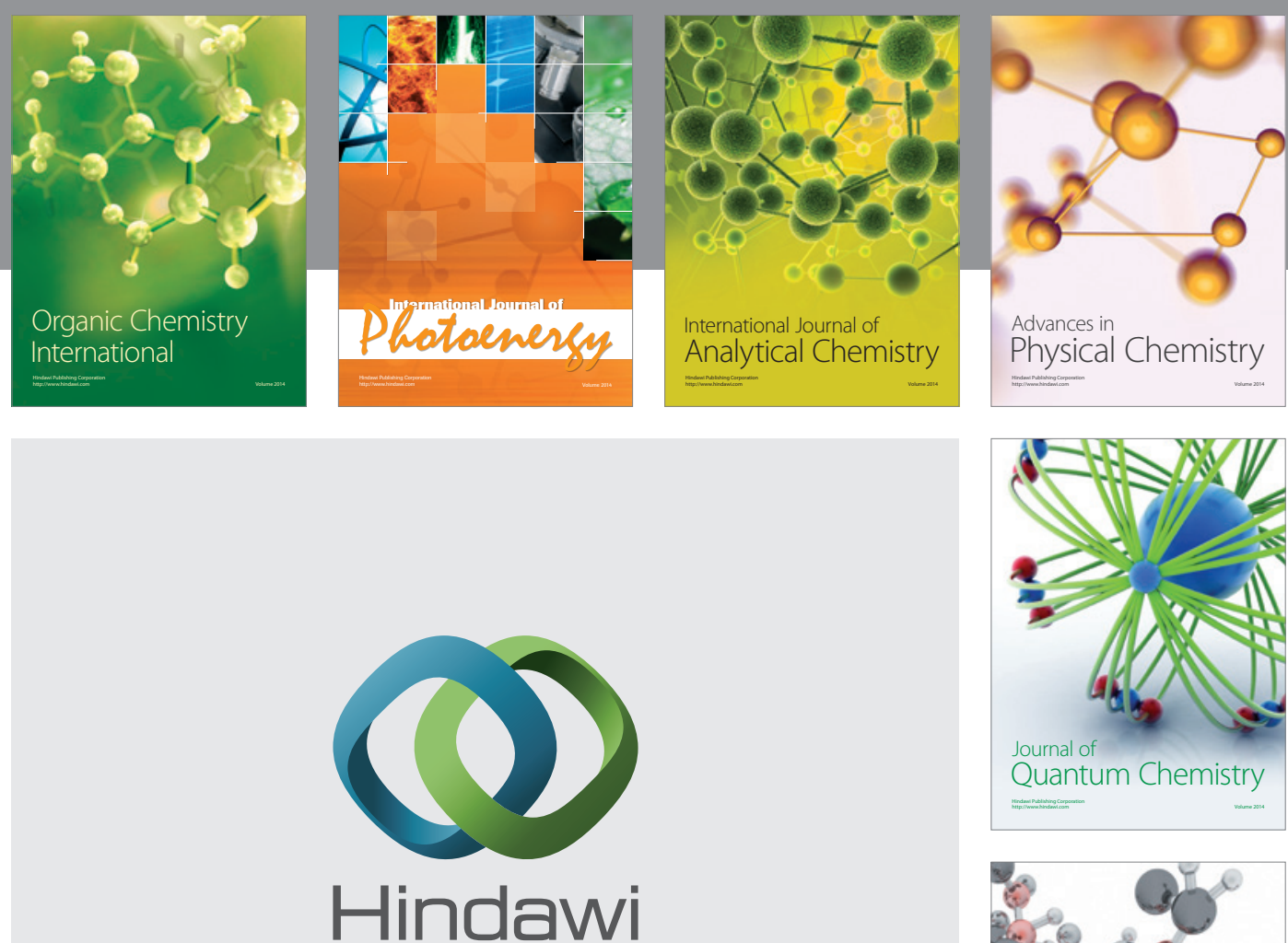

Submit your manuscripts at

http://www.hindawi.com

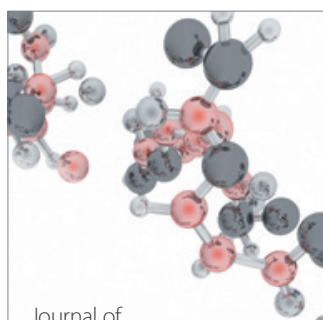

Analytical Methods

in Chemistry

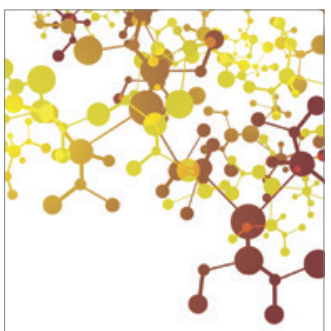

Journal of

Applied Chemistry

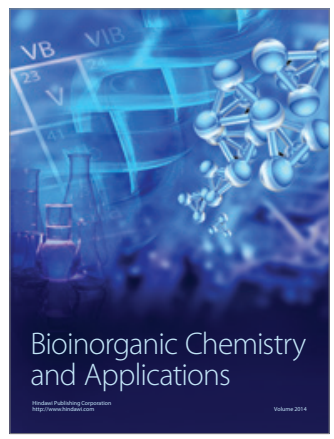

Inorganic Chemistry
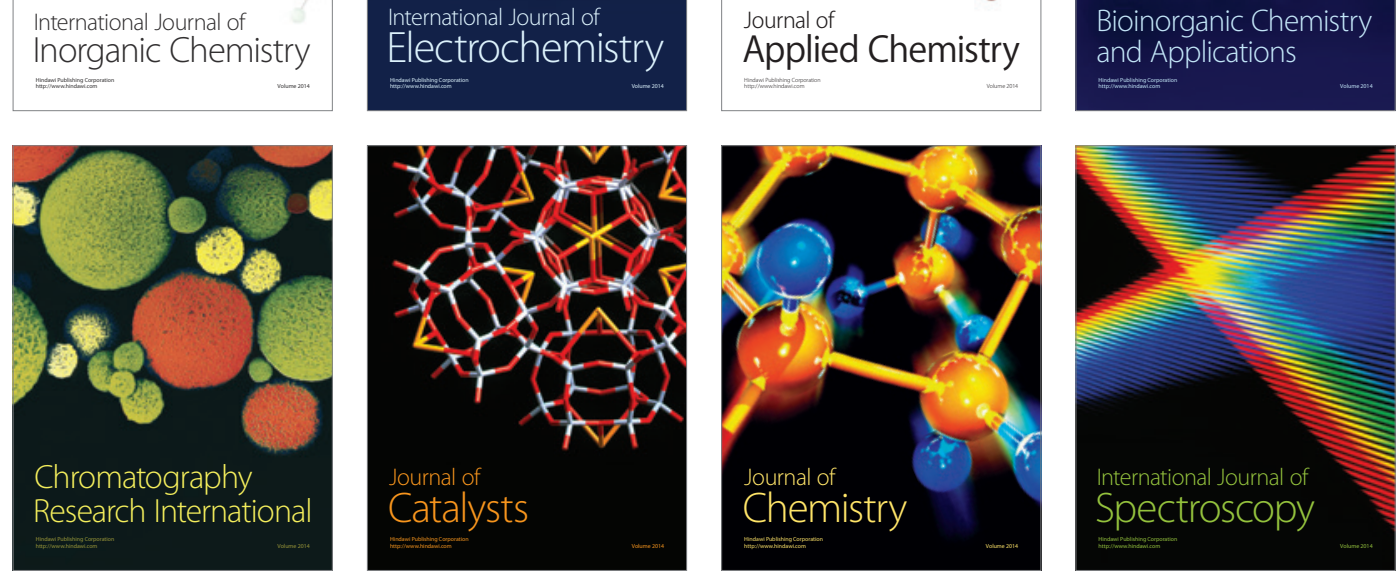